\title{
Transformation of The Pesantren Community's Therapeutic Relationship in Online Learning
}

\author{
Samsul Arifin, ${ }^{1,}$ Mohamat Hadori, ${ }^{2}$ Yohandi, ${ }^{3}$ \\ \{email: syamsulahasan@ibrahimy.ac.id, ${ }^{1}$ hadorimohamat@mail.ugm.ac.id, ${ }^{2}$ yohandi1986@gmail.com, ${ }^{3}$ \\ \} \\ 1,2,3 Universitas Ibrahimy, Situbondo, Indonesia
}

\begin{abstract}
This study aims to reveal the transformation of the therapeutic relationship in online learning during the COVID-19 pandemic at Pondok Pesantren Salafiyah Syafi'iyah Sukorejo Situbondo. Qualitative research methods; ethnographic-hermeneutic. Results: The forms of online learning or cyber-da'wah carried out by pesantren include: Ngaji Online activities and Gerak Batin (praying). In both services, there is a change in the meaning of baraka in a therapeutic relationship, from a sense of "teduh (restful)" to a sense of "tenteram (comfort)". In the face-to-face da'wah service system, therapeutic results from the warmth of the relationship by looking directly at the face of the kiai who brings a sense of feel calm and restful. In the therapeutic online da'wah service system switches to environmental settings that provide a sense of peace and comfort. But both in the face-toface and online systems, students still have a spiritual relationship with their kiai which is also a therapeutic key
\end{abstract}

Keywords: COVID-19, therapeutic relationship, pesantren

\section{Introduction}

One of the important behaviors of students is the search for and hope for their lives to obtain baraka (blessings) from the Kiai (scholars from boarding school). Baraka can be obtained by serving the kiai and following the teachings taught by the Kiai. The students, especially senior students, many thought that they were serving and took part in the kiai study in a more face-toface manner. With a face-to-face model, students can hear and see the kiai's face directly. Baraka will emanate from the quality of the kiai's character to the students through a face so that students will feel calm and restful. No wonder, if students follow the recitation, they will surely compete near the kiai.

But what about the situation during a COVID-19 pandemic that no longer allows for face-to -face study? How about the baraka search behavior that has been achieved with a face-to-face model? On the other hand, the pesantren began to develop online da'wah services or cyberda'wah. This step is carried out by considering the characteristics of COVID-19 which can be transmitted through human contact [1], [2], and the government's determination to maintain social distancing and physical distancing.

Before the COVID-19 pandemic, pesantren held face-to-face prayer meetings to fill holidays ahead of and during Ramadan. Usually, many students do not go home, they follow the study of several books. However, during the COVID-19 pandemic, 90\% of the 12,247 Pesantren Salafiyah Syafi'iyah students returned to their homes. Pesantren Salafiyah Syafi'iyah also 
changed its teaching system. The pesantren holds an online book study which is followed by students in their homes. Likewise, some dhikr assemblies are conducted online, simultaneously, and at home.

With the online da'wah service model, students also experience behavioral changes in understanding baraka. There is a shift in the meaning of "baraka" from the peace of looking at the face of the kiai to security and comfort. Baraka which emanates from the quality of the kiai's personality becomes a baraka that comes from an environmental setting that guarantees safety. For students, baraka is key in the therapeutic relationship [3], [4].

Some research on cyber-counseling highlights the weaknesses of the online system. One of them, about the lack of physical presence in communication in the online system can cause a lack of familiarity, trust, and commitment in therapeutic relationships. As a result, it can weaken the development of a therapeutic foundation between counselor and counselee [5]. From research on online mental health care perceptions to 2,098 professionals, they are worried and do not fully provide online consultation [6]. However, several other studies, show that this will not interfere with the therapeutic relationship. The online system is an attraction for some people who have a closed personality. With an online system, they feel more comfortable because they are at home [7].

But even so, psychological research related to phenomena and human behavior in the online world is still small. Even though there are many important issues that need to be studied [8]. Therefore, this study tries to answer these challenges. This study seeks to uncover some forms of online proselytizing services and the meaning of blessing in the therapeutic relationship between the kiai and the students of the Salafiyah Syafi'iyah Sukorejo Situbondo in the midst of the COVID-19 period. This research is a development in the therapeutic relationship theory or therapeutic alliance in the field of counseling, psychology, psychotherapy, and Islamic studies.

There are many different counseling experts about therapeutic events; depends on the theoretical approach used. For humanists (eg person-centered therapy counseling), therapeutic changes occur when there is self-disclosure in the context of a trustworthy relationship between counselor and counselee. With an emphasis on the quality of relationships which are core conditions, that is congruent, empathy, and unconditional acceptance. Therefore the quality of communication relationships in counseling, plays an important role for therapeutic events [9]-[11].

For behavioral circles, the quality of the relationship between counselor and counselee is indeed a necessity for the effectiveness of counseling. But the main focus is not on the quality of the relationship but the intervention process. The main purpose of behavioral counseling changes the counselee's performance in social situations in real life everyday through structured training or intervention. Thus the therapeutic relationship is collaboration between counselor and counselee [11], [12].

This study reviews several local pearls of wisdom of pesantren, especially those that occur at Salafiyah Syafi'iyah Sukorejo Situbondo, East Java, which can be absorbed in counseling. Counseling based on local wisdom of pesantren is based on the values of religiosity (fiqh norms and sufistic life codes) and locality values around the pesantren. This pesantren-based counseling approach uses a balanced approach (at-tawazun) from various elements and potentials within the counselor, counselee, and environment and refers to the benefit (wisdomoriented counseling approach). The role of counseling is to help the counselee improve his anger, which always invites the ugliness of being a private khaira ummah, a person who always invites good, prevents badness and has faith in God.[3], [13]-[15] 


\section{Method}

This research uses a qualitative research method of an ethnographic-hermeneutic type. Reasons for choosing this method: First, this research reveals and describes the patterns, typologies, and cultural categories of the pesantren community. The ethnography is related to the disclosure of patterns, typologies, and categories of a community or group. The main purpose of ethnographic research is to try to uncover and understand the various meanings that cultural practitioners consider normal, then researchers try to explain the new understanding gained in the culture [16].

The researcher acts as a research instrument as well as a data collector. Researchers also do full participation. The reason for choosing a location in the Salafiyah Syafi'iyah Sukorejo, is because the Pesantren Sukorejo is a large boarding school. Total students are 12,247 people and millions of alumni. 59.8\% of children of farmers, $18.9 \%$ of children of fishermen, $15.8 \%$ of children of traders, $3.45 \%$ of children of civil servants, and $2.1 \%$ of children of scholars. They come from various regions in Indonesia and some even come from Malaysia, Singapore, and Thailand [17]. Salafiyah Syafi'iyah is also affected by the COVID-19 pandemic and prone to rapid transmission to thousands of students. Whereas students are always in contact with the dam and cannot keep their social and physical distance; for example shaking hands, praying in congregation, sleeping close together, or other physical contacts. Likewise, Salafiyah Syafi'iyah students totaling 12,247 people. On average 30-40 students occupy a 7 x 4-meter dormitory. If you sleep, because the dormitory is insufficient, there are those on the terrace porch, mashallah, or terrace of the school building. That way, the potential risk of transmission of COVID-19 in pesantren is quite large. The steps of data analysis can be simplified into three activities that occur simultaneously, namely data reduction, data display, and conclusion drawing.

\section{Result and Discussion}

Pondok Pesantren Salafiyah Syafi'iyah Sukorejo undertaking efforts to prevent and break the chain of the spread of COVID-19, among others by conducting the uzlah technique. This "uzlah" technique is similar to the "self-isolation" or "self-quarantine" technique. "Selfisolation" or "self-quarantine" is known as a technique in breaking the chain of the spread of COVID-19 [18]-[20]. The uzlah technique is a technique to limit the interaction of students from outside pesantren. In the view of the Sufis adopted by the pesantren, the biggest safety factor is not too often associating with others because they do uzlah [21]. Even though the students are enjoying a vacation at their own homes, the Salafiyah Syafi'iyah expects them to take part in the online da'wah service organized by the pesantren. The forms of online learning or cyber-da'wah services include:

1.

2.

3. 


\subsection{Ngaji online.}

During the Ramadan holiday, usually, some students do not go home but attend book studies at pesantren. Usually, in the middle of Ramadan, these books are finished by the kiai. During the COVID-19 outbreak season of Ramadan, the Salafiyah Syafi'iyah promotes Ngaji Online activities in Sya'ban or April 9, 2020, and optimizes the use of internet-based media and cable television. Students who are at home take part in the recitation online. Some online media, namely Salafiyah Syafi'iyah radio (Radio Bhasa FM, Da'wah Buana Swara FM 104.9 Mhz, and Da'wah Media) which broadcast live Ngaji Online programs streaming and television media (Salafiyah Syafi'iyah Sukorejo TV / S3) TV).

\subsection{Gerbat online}

Gerbat is an abbreviation of gerak batin or riyadhah ruhaniyyah or spiritual practice. In the context of counseling, this gerbat includes the most important behavioral change techniques for pesantren [3], [22], [23]. This gerbat is in the form of prayers to prevent an outbreak of disaster. This technical decision making of gerbat, because gerbat serves to maintain mental health [24]. One of the wisdom of the gerbat is for the healing process of a depressed heart.

For pesantren, mental health is important. Because the focus of Islmic boarding school counseling, is personal and community is not a matter of counselee. What is addressed is the human heart (personal and community), not the problem so that their hearts will be roomy, calm, peaceful, and peaceful. Because this counseling believes, if humans become the personal khaira ummah then the problem by itself can be overcome [3], [25], [26]. In addition to mental health or spiritual life, pesantren emphasize physical health.

The gerbat online, among others: First, Ratibul Haddad. Ratibul Haddad is also called dhikr, ri'ayah whose purpose is to preserve (ri'ayah) the benefit of the heart for its readers. With the permission of Allah, Ratibul Haddad will guard an area where people read Ratibul Haddad [27], [28]. The Ratibul Haddad becomes a routine reading at the Salafiyah Syafi'iyah after every Asyar prayer and in various activities, especially the activities of students and alumni of Sukorejo. Because of that, Ratibul Haddad was called the soul or soul of Sukorejo students.

Secondly, Istighatsah Jum 'at Manis online. Before the COVID-19 outbreak, the istighatsah was carried out directly by tens of thousands of people from Situbondo, Bondowoso, Jember, Banyuwangi, Probolinggo, Bali, and others. The Istighatsah began on 24 Rabiul Awal $1425 \mathrm{H}$ or 13 May 2004 by K.H.R. Ach. Fawaid As'ad and now continued by K.H.R. Ach. Azaim Ibrahimy. Istighatsah is a request from Allah that our intentions will be achieved. By doing istighatsah together, our intentions will likely be quickly achieved [28], [29].

\subsection{Therapeutic Relationship}

The pesantren community in educating students emphasizes the quality of the relationship between the kiai and students or vice versa. The students believe, by maintaining the quality of the relationship their lives will be baraka and useful both for themselves and for others. Therefore, students will continue to maintain contact with their kiai and teachers at any time.

The relationship of students to kiai or clerics who teach Ngaji Online or Gerbat Online has changed orientation. When in the pesantren students who attend the book study face to face, find shade, and calm when they look at the kiai's face. They feel calm and peaceful around the kiai. Because of this, students are competing to be near the kiai. 
But when joining Ngaji Online, students experience a change in taste. They now feel more secure and comfortable. One of the weaknesses of this Ngaji online is the difficulties and limitations in fostering good and warm relations between kiai and students. In the context of cyber-counseling, this therapeutic relationship is not as friendly and warm as in the context of face-to-face counseling [30]. Through this therapeutic relationship is one of the keys to the healing process. Even in person-centered therapy counseling, this warm relationship is sufficient for the healing process. The quality of the counselor's personality will radiate and can cause positive counselee feelings. These positive feelings lead to the creation of a therapeutic climate that is positive interpersonal and emotional. The quality of the counselor's personality that can cure the counselee is congruence or genuine, accurate empathy, and unconditional positive regard [9]-[12], [31], [32].

Weaknesses in the warmth of the relationship, in the tradition of pesantren can be covered with ruhaniyah or spiritual relationships that have been established between the kiai and students. Students who take the teaching model face to face or online, but they still have a ruhaniyah or spiritual relationship with the kiai. They don't just rely on outer relationships; both through face to face and online, but they still maintain a spiritual relationship.

The spiritual relationship between the kiai and students becomes an emphasis in the pesantren. One of the founders of the Salafiyah Syafi'iyah gave advice, a kiai must be "asambung" or " relationship" — that must be united — with students. Likewise, a student must "asambung" with the kiai. From here later, baraka will emerge; so that the message of the kiai will always be remembered and remain embedded in the hearts of students or the community [33]-[35].

According to Kiai Azaim, there are two aspects of communication and interaction between pesantren and alumni, namely the physical and spiritual aspects. According to Kiai Azaim the relationship between students and kiai, there are four categories. First, the asanding-asambung; namely physically and spiritually the two are close together and interact. Second, asanding-tak asambung;; that is, they are close together but their spirits do not interact. Third, it is tak asanding-asambung; that is, they are far apart but their spirits always interact. Fourth, tak asanding-tak asambung; both their bodies and spirits do not interact and are far apart [34]

Judging from the category of the Kiai Azaim, students who take part in the activities of the Ngaji Online or Gerbat Online can be categorized as tak asanding-asambung. Physically the students are far apart but emotionally and spiritually they establish interactions and relationships in the scientific arena.

From the perspective of counseling, cyber-da'wah services carried out by pesantren are oriented more towards a behavioral approach than a person-centered. Whereas all this time, in some studies, the orientation of pesantren is more person-centered. In other words, the meaning of baraka that contains therapeutic changes from "teduh (restful)" of looking directly at the kiai's face to being oriented towards virtual baraka for "tenteram" (safety and comfort). The healing process changes from the quality of the kiai's personality which directly radiates to his students to an environmental setting that provides a sense of security and comfort through online media. But in the pesantren tradition, therapeutic can also be through the spiritual relationships between the kiai and students [3]. Thus there is a harmonization between the batiniyah relationships and the lahiriyah relationships, both face-to-face and online [32].

Judging from the theory of cyber-counseling, there is debate about whether online counseling (cyber-irshad) that facilitates therapeutic communication is a new paradigm in the science of counseling or not. There are opinions that say online counseling is a reversal of faceto-face counseling, so it doesn't need a different theoretical framework. But there are also 
opinions, online counseling is a new type of therapeutic intervention with certain characteristics, which is not a substitute for face-to-face intervention. Online counseling as a resource that can be adjusted and flexible with the potential to complement and support other types of interventions [5]. The results of this study indicate cyber-da'wah services (including cyberirshad) tend to support the conclusion that this therapeutic service is a new type of intervention and as a supporter of face-to-face da'wah

\section{Conclusion}

Pesantren are very responding to developments in the community, including the COVID-19 pandemic problem. Among other things, by changing the da'wah service from a face-to-face system online. Models of cyber-da'wah services such as Ngaji Online and Gerbat (prayer) activities online. The activity that usually takes place face-to-face between the kiai and students in the pesantren complex becomes a long-distance virtual world at each student's home. Of course, there is also a therapeutic shift in the context of the relationship.

In the face-to-face da'wah service system, therapeutic is due to the relationship of warmth by looking directly at the kiai's face which makes students feel "teduh (restful)". In the therapeutic cyber-da'wah service system switches to environmental settings that make students feel at "tenteram" (ease and comfortable). Thus, the warmth of a relationship that makes students feel shady turns to environmental interventions that make students feel at ease. In the cyber-da'wah system, the warmth of relationships begins to weaken. However, this weakness can be covered up because of the ruhaniyah relationship or spiritual relationship between the kiai and students who still feel strong. This spiritual relationship has become a key therapeutic for pesantren.

\section{References}

ADDIN Mendeley Bibliography CSL_BIBLIOGRAPHY [1] L. Meng, F. Hua, and Z. Bian, "Coronavirus Disease 2019 (COVID-19): Emerging and Future Challenges for Dental and Oral Medicine," J. Dent. Res., vol. 2019, pp. 1-7, 2020.

[2] Y. Tong et al., "Early Transmission Dynamics in Wuhan, China, of Novel Coronavirus-Infected Pneumonia," N. Engl. J. Med., vol. 382, no. 13, pp. 1199-1207, 2020.

[3] S. Arifin, At-Tawazun: Psikologi dan Konseling Berbasis Pesantren untuk Membentuk Karakter Khaira Ummah. Malang: Literasi Nusantara, 2020.

[4] S. Arifin and A. Zaini, "Transformative Da'wah Through Counseling for the Career Development of Coffee Farmer Groups in the Tourism Village Banyuwangi," J. Konseling Reli., vol. 10, no. 2, pp. 215-231, 2019.

[5] P. Li, R. Aga, M. Jaladin, and H. S. Abdullah, "Understanding the two sides of online counseling and their ethical and legal ramifications," Procedia - Soc. Behav. Sci., vol. 103, pp. 1243-1251, 2013.

[6] K. A. Becker-blease, D. Ph, and W. E. T. Al, "Online Mental Health Treatment: Concerns and Considerations," Cyberpsychology Behav., vol. 10, no. 3, pp. 453-459, 2007.

[7] E. Robinson, "Online counselling, therapy and dispute resolution A review of research and its application to family relationship services," AFRC Brief., pp. 1-15, 2006.

[8] B. Takwin, "Pesan dari Editor-in-Chief: Tantangan Psikologi Siber," J. Psikol. Sos., vol. 18, no. 01, pp. 3-4, 2020 .

[9] C. R. Rogers, Counseling and Psychotherapy Newer Concepts in Practice. Cambridge: The Ribersibe Press, 1942. 
[10] E. Gillon, Person-Centred Counselling Psychology: An Introduction. London: SAGE Publications Ltd, 2007.

[11] Gerald Corey, Theory and Practice of Counseling and Psychotheraphy. Belmont: Thomson Higher Education, 2009.

[12] McLeod, An Introduction to Counselling Third Edition. New York,: Open University Press, 2003.

[13] S. Arifin, "Pesantren -Based Counseling in Changing The Behaviour of The Community of Former Bajingan Being Personal Characterless 'Pelopor," Umr. - Int. J. Islam. Civilizational Stud., vol. 07, no. 03, pp. 59-75, 2020.

[14] A. S. Arifin, Risalah At-Tadzkirah fi 'Uqdin Nihah. Situbondo: Pondok Pesantren Sukorejo, 1975.

[15] S. Arifin, A. Zaini, and K. Wibawa, "Strengthening Family - Based Local Cultural Values in the Conflicting Area and Marine Ecotourism of Situbondo Indonesia," J. Community Dev. Res. (Humanities Soc. Sci., vol. 14, no. 2, pp. 50-62, 2021.

[16] P. J. Spradley, Participant Observation. New York,: Holt Rinehart and Winston, 1980.

[17] P. P. S. Syafi'iyah, "Profil Pondok Pesantren Salafiyah Syafi'iyah Sukorejo Situbondo," 2019

[18] B. M. Bodas and K. Peleg, "Self-Isolation Compliance In The COVID-19 Era Influenced By Compensation: Findings From A Recent Survey In Israel," HealthAffairs, vol. 39, no. 6, pp. 1-4, 2020.

[19] S. K. Brooks et al., "Rapid Review The psychological impact of quarantine and how to reduce it: rapid review of the evidence," Lancet, vol. 395, no. 10227, pp. 912-920, 2020.

[20] W. H. Organization, "Mental health and psychosocial considerations during the COVID-19 outbreak," World Heal. Organ., no. March, pp. 1-6, 2020.

[21] Al-Muhasibi, Renungan Suci Bekal Menuju Takwa (Terjemah Al-Washaya). Jakarta: Pustaka Azzam, 2001.

[22] S. Arifin and H. Munfaridah, "Pengembangan Desain Konseling Berbasis Pesantren dengan Pendekatan Service-Learning,” J. Bimbing. dan Konseling Islam, vol. 08, no. 02, pp. 110-132, 2018.

[23] S. Arifin, Sang Pelopor: Kisah Tiga Kiai dalam Mengelola Bekas Bajingan. Surabaya: Pena Salsabila, 2014.

[24] S. Arifin and A. Zaini, "Decision of Implementing Uzlah and Gerbat Techniques in Islamic Boarding School as Preparedness Response for Covid-19 Pandemic," Unnes J. Public Heal., vol. 9, no. 2, 2020.

[25] S. Arifin, "Hidup Berkat dan Sehat: Kearifan Kiai Pesantren dalam Memperbaiki Kesehatan Jiwa Masyarakat dalam Kitab Al-Adzkar Al-Yaumiyyah," in Tradisi dan Kebudayaan Nusantara, S. Al Qutuby and I. Y. M. Lattu, Eds. Semarang: Lembaga Studi Sosial dan Agama (eLSA) Press, 2019, pp. 58-83.

[26] S. Arifin and A. Zaini, "Dakwah Inklusif di Kalangan Bajingan: Membedah Komitmen Bekas Bajingan dalam Membangun Peradaban Perspektif Psikologi Sosial," J. Dakwah, vol. XIX, no. 1, pp. 29-50, 2018.

[27] U. Ibrahim, Thariqah Alawiyah: Napak Tilas dan Studi Kritis Atas Sosok dan Pemikiran Allamah Sayyid Abdullah Al-Haddad, Tokoh Sufi Abad Ke-17. Bandung: Mizan, 2001.

[28] A. A. Ibrahimy and S. Arifin, Kiai Fawaid As'ad: Kepribadian, Pemikiran, dan Perilaku Politik. Situbondo: Tanwirul Afkar, 2018.

[29] S. Arifin and Wisri, "Politik Kebangsaan Kiai Pesantren (Studi Kepribadian dan Perilaku Politik K.H.R. Ach. Fawaid As'ad Situbondo)," in 3rd Annual Conference For Muslim Scholars (AnCoMS), 2019, pp. 343-353.

[30] A. Samsul and A. F. Risma, "The Model of Development Therapeutic Speech in the Digital Era: A Study of 'Interpretation of Al- Mishbah ' for Cyber-Counseling Services," in Proceedings of the 19th Annual International Conference on Islamic Studies, AICIS 2019, 1-4 October 2019, Jakarta, Indonesia, 2020.

[31] J. . Flanagan and R. . Lanagan, Counseling and Psychotherapy Theories in Context and Practice: Skills, Strategies, and Techniques. New Jersey: John Wiley \& Sons, Inc, 2004.

[32] S. Arifin, "Dinamika Perubahan Relasi Kiai Santri Pada 'Ngaji Online' di Masa Pagebluk COVID19," J. Kependud. Indones., vol. 1, pp. 75-80, 2020.

[33] S. A. Hasan, Kharisma Kiai As'ad di Mata Umat. Yogyakarta: LkiS, 2003. 
[34] A. A. Ibrahimy and S. Arifin, Risalah Hati: Trilogi Biografi Nyai Zainiyah As'ad. Situbondo: Tanwirul Afkar, 2019.

[35] S. Arifin, "Pengembangan Self-Concept Khaira Ummah Santri Perempuan Menyongsong Era Society 5.0 Perspektif Pengembangan Karier," Hisbah J. Bimbing. Konseling dan Dakwah Islam, vol. 17, no. 1, pp. 33-60, 2020. 